\title{
ERGONOMIKA: DALYKO TURINYS IR METODOLOGIJA
}

\author{
Vilma Dudoniené $\dot{1}^{1}$ (https://orcid.org/0000-0003-3954-9271), \\ Anelè Gedmantaitè ${ }^{1}$, Eija Mammela ${ }^{2}$, Marion Karpi ${ }^{3}$ \\ Lietuvos sporto universitetas $^{1}$, Oulu taikomuju mokslu universitetas ${ }^{2}$, \\ Turku taikomuju mokslu universitetas ${ }^{3}$, Suomija
}

\section{SANTRAUKA}

Pagrindimas. Sveikatos priežiūros specialistai dažnai patiria su darbine veikla susijusius kaulų ir raumenų pažeidimus dèl netinkamų paciento kūno padèties keitimo judesių. Todẻl svarbu studentus, kurie mokosi sveikatos priežiūros srityje, išmokyti teisingų būdų ir metodų. Tokios žinios paprastai suteikiamos ergonomikos dalyko metu. Skirtingos mokymo institucijos turi skirtingas mokymo programas ir neaišku, ar jas baigusieji gavo vienodas arba panašias žinias bei ịūdžius.

Tikslas - išanalizuoti skirtingų Lietuvos aukštujų mokyklų, rengiančių sveikatos priežiūros specialistus, ergonomikos dalyko mokymo turinị ir nustatyti mokymo skirtumus tarp skirtingų institucijų.

Metodai. Atlikta anketinė apklausa, kurioje dalyvavo dešimties Lietuvos aukštųjų mokyklų, rengiančių kineziterapeutus, ergoterapeutus ir slaugytojus, atstovai. Apklausa atlikta ịgyvendinant ES projektą „Ergonominio švietimo atnaujinimas“ sveikatos priežiūros studentams Europos aukštosiose mokyklose (angl. Reniewing of Ergonomic Education RENE in European HEIs), kuriame dalyvauja šešios šalys partnerès: Ispanija, Portugalija, Suomija, Estija, Lietuva ir Slovėnija. Šiuo projektu siekiama sukurti tarptautinị saugaus pacientų kūno padèties keitimo ir perkẻlimo mokymų kursą.

Rezultatai. Nustatyta, kad daugumoje (70 proc.) aukštojo mokslo institucijų, rengiančių sveikatos priežiūros specialistus, ergonomikos dalykas pateikiamas kaip atskira disciplina, jam skirtingose mokymo įstaigose skiriamas skirtingas kreditų skaičius: nuo vieno iki penkių kreditų (ECTS), kai kuriose institucijose (30 proc.) ergonomikos žinios integruotos ị kitus dalykus. Ergonomikos dalyko mokymo turinys ir metodologija skiriasi tarp institucijų.

Išvados. Lietuvos aukštosiose mokyklose, rengiančiose kineziterapeutus, ergoterapeutus ir slaugytojus, ergonomikos mokymo turinys, metodologija ir turimos priemonės skiriasi. Siekiant, kad visi absolventai ịgytų vienodas žinias ir ịgūdžius, reikètų praplèsti ir suvienodinti mokymo turinį.

Raktažodžiai: ergonomika, paciento priežiūra, mokymo turinys, metodai

\section{IVADAS}

Mokslinių tyrimų duomenimis, kineziterapeutai dažnai patiria su darbine veikla susijusius kaulų ir raumenų pažeidimus (Haleem et al., 2020). Jungtinèje Karalystèje atliktas tyrimas parodè, kad kineziterapeutai vidutiniškai buvo 31,2 metų amžiaus, kai patyrė sunkiausią traumą; 32 proc. tyrimo dalyvių nurodè, kad skausmą patyrè per pirmus penkerius darbo metus, net 12 proc. tiriamųjų skausmą pajuto

Copyright (C) 2021 Vilma Dudonienè, Anelè Gedmantaitė, Eija Mammela, Marion Karpi. Published by Lithuanian Sports University.

This is an Open Access article distributed under the terms of the Creative Commons Attribution 4.0 International License, which permits unrestricted use, distribution, and reproduction in any medium, provided the original author and source are credited. 
būdami kineziterapijos studentais (Glover, McGregor, 2005). Kiti tyrejjai nurodo, kad skausmą, susijusi su darbine veikla, dar besimokydami arba per pirmus penkerius darbo metus patiria 50 proc. kineziterapeutų (Cromie et al., 2000). Nugaros skausmais dažnai skundžiasi ir slaugytojai (Videman et al., 2005). Kaulų ir raumenų ligų požymiai sąlygoja slaugos profesijos produktyvumo praradimą, nedarbingumo atostogas, specialybės keitimą (Kox et al., 2020), netgi studijų nutraukimą (Lövgren et al., 2014). Šie skaičiai kelia ypač didelị nerimą, nes yra daug didesni nei būtų galima tikètis jaunai, sveikai populiacijos daliai (Tamminen et al., 2019). Viena iš priežasčiu gali būti ta, kad sveikatos priežiūros specialistai profesiniame mokyme negauna ịrodymais pagrịsto saugaus pacientų kèlimo, perkèlimo mokymo. Tai įrodo apklausos, atliktos Europoje ir JAV. Suomijoje atlikta apklausa apie saugaus paciento perkèlimo mokymą parodè didelius mokymo laiko skirtumus ir tai, jog per pastarajị dešimtmetị buvo paprastai mokoma fiziškai sunkių ir nesaugių pacientų perkèlimo metodų (Tamminen et al., 2019). Apklausos Olandijoje rezultatai kiek geresni: vidutiniškai 11,4 val. buvo skiriamos paciento kèlimo, perkèlimo ergonomikai. Beveik pusė mokyklų moko ergonomikos, kaip specialaus kurso ir 80 proc. mokyklų integruoja paciento perkèlimo mokymą ị kitas temas (Vries et al., 2011). Vokietijoje atlikto tyrimo metu, nustatyta, kad stinga profesinių kokybės standartų ir vadovèlių apie saugų paciento kūno padèties keitimą ir daromos prielaidos dèl nepakankamos dèstytojų kompetencijos (Hermann, Michaelis, Schulz, 2014). $2005 \mathrm{~m}$. JAV buvo pasiūlytas saugaus paciento valdymo modulis (Waters, 2009), tačiau net JAV slaugos mokyklos nemoke ịrodymais pagrịstos praktikos (Powell-Cope et al., 2008).

Nors yra žinoma nedaug apie geriausius metodus, kaip veiksmingai išmokyti saugių paciento perkèlimo būdų (Eberth, Provident, Chase, 2019), kai kurie metodai yra pripažinti kaip geriausia praktika, kurios reikia laikytis - tai tarpdisciplininis bendradarbiavimas (McCrorie et al., 2017), praktika su pacientais ir mokymasis grupeje (Boucaut, Howson, 2018).

Šio tyrimo tikslas buvo išanalizuoti ergonomikos dalyko turinị ir poreikị skirtingose institucijose, rengiančiose sveikatos priežiūros specialistus.

\section{METODAI}

Apklausa buvo atlikta įgyvendinant ES projektą „Ergonominio švietimo atnaujinimas" sveikatos priežiūros studentams Europos aukštosiose mokyklose (angl. Reniewing of Ergonomic Education RENE in European HEIs), kuriame dalyvauja šešios šalys partnerès: Ispanija, Portugalija, Suomija, Estija, Lietuva ir Slovėnija. Šiuo projektu siekiama sukurti tarptautinị saugaus pacientų valdymo ir perkèlimo mokymų kursą. 
Duomenu rinkimas. Duomenys surinkti atliekant internetinę apklausą, kuriai anketa buvo sukurta „Webropol“ pavidalo ir išplatinta Lietuvos aukštosioms mokykloms, rengiančioms sveikatos priežiūros specialistus. Anketą reikejjo pildyti laikotarpiu nuo 2019 m. gruodžio mèn. iki $2020 \mathrm{~m}$. vasario mèn. Atsakymas ị anketos klausimus buvo traktuojamas kaip sutikimas dalyvauti tyrime.

Pagrindiniai tyrimo klausimai:

1. Kiek ergonomikos dalyko kreditų dèstoma Lietuvos aukštujų mokyklų sveikatos studijų programose, kokios gairès naudojamos ergonomikos mokyme?

2. Ar ergonomika yra savarankiškas kursas ir kokios temos yra nagrinejjamos kurse?

3. Kiek svarbus ergonomikos dalykas ir ką reikètų daryti ir (ar) tobulinant dalyko turinį?

Imtis. Lietuvoje atsakymai ị anketos klausimus buvo gauti iš dešimties aukštụjų mokyklų: 50 proc. respondentų buvo katedrų vedejai, 40 proc. - dèstytojai, 10 proc. - programos vadovai. Didžioji dauguma (90 proc.) atsakiusiujų i anketos klausimus buvo kineziterapijos studiju programos atstovai.

Matematine statistika. Anketos duomenis išanalizavo projekto partneriai iš Turku Taikomųjų mokslų universiteto. Duomenys pateikiami procentine reikšme.

\section{REZULTATAI}

Kreditu skaičius skiriamas ergonomikos mokymui. Lietuvos aukštosios mokyklos skiria skirtingą ECTS kreditu skaičių ergonomikos mokymui. Kai kuriose mokyklose ergonomikos žinios yra integruotos ị kitus dalykus (1 pav.)
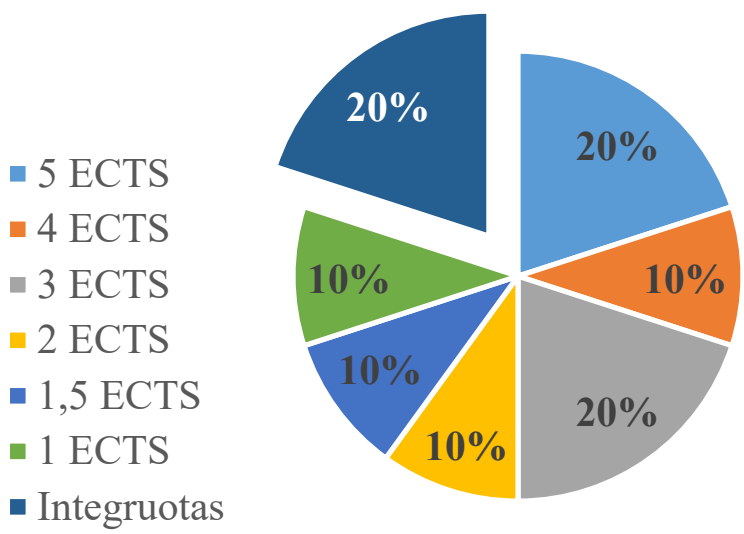

1 pav. Kreditų (ECTS) skaičius, skiriamas ergonomikos dalykui 


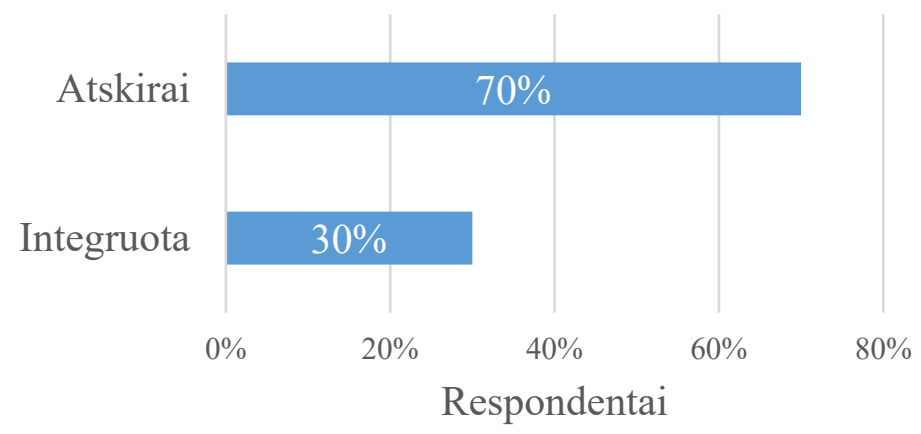

2 pav. Respondentų atsakymų pasiskirstymas pagal ergonomikos dalyko mokymą

Paciento kūno padèties keitimo (angl. patient handling) mokymas. Nustatyta, kad daugelyje Lietuvos aukštujjų mokyklų saugaus paciento kūno padèties keitimo mokoma atskiroje disciplinoje (2 pav.).

Pagrindines temos ergonomikos dalyko mokyme. Respondentai, nurodydami pagrindines temas, ịtrauktas ị ergonomikos dalyko turinį, dažniausiai pasirinko judesių analizę ir aplinkos dizainą (3 pav.).

Judesių analizè (natūralūs judesiai)

Aplinkos dizainas (darbo erdvès organizavimas)

Biomechanika (su antropometrija)

Darbo vietos saugumas

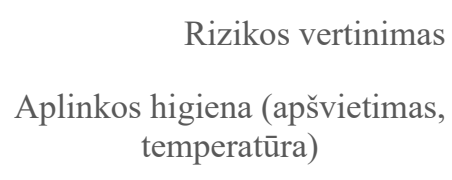

$0 \% \quad 10 \% 20 \% 30 \% 40 \% 50 \% 60 \% 70 \% 80 \% 90 \% 100 \%$

Respondentai

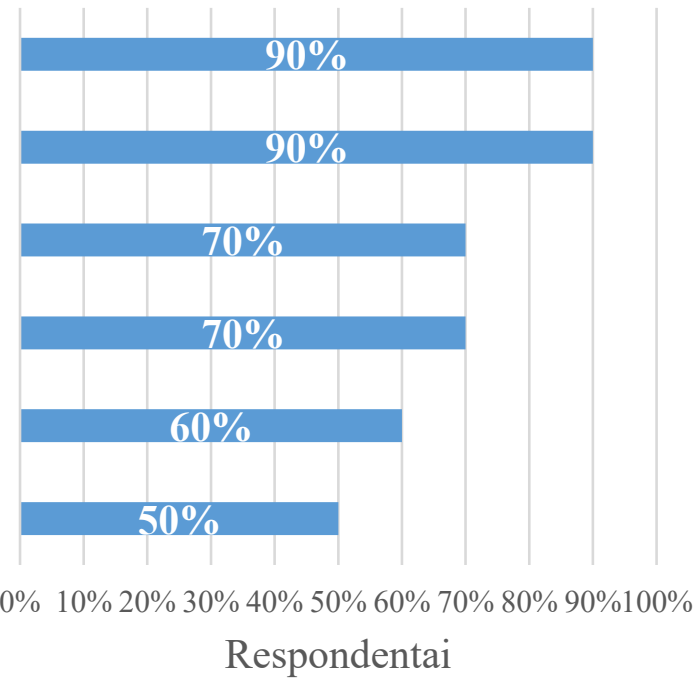

3 pav. Respondentų atsakymų pasiskirstymas pagal ergonomikos dalyko pagrindines temas 
Mokymo metodai. Apklausoje dalyvavusios Lietuvos aukštosios mokyklos, mokant ergonomikos, naudoja šiuos mokymo metodus: teorines paskaitas (100 proc.), praktines ikiklinikines pratybas ( 90 proc.), atvejo analizes (60 proc.), simuliacijas (70 proc.) ir klinikines pratybas ( 70 proc.).

Ergonomikos dalyko svarba. Analizuojant respondentų atsakymus ị klausimą „Kaip svarbu jūsų dèstomoje disciplinoje mokyti ergonomiško ir saugaus pacientu padèties keitimo?"“, 60 proc. respondentų atsakè, kad labai svarbu, 20 proc. - labai svarbu, po 10 proc. - svarbu ir visai nesvarbu.

Ergonomikos dalyko mokymo kokybe. Nustatyta, kad apibūdinant ergonomikos dalyko mokymo kokybę savo aukštojoje mokykloje, 50 proc. respondentų nurodè, kad mokymo kokybė yra sąlyginai gera, 30 proc. - gera, 10 proc. - puiki, 10 proc. - bloga.

Pagalbinès priemonés ergonomikos mokymui. Nustatyta, kad daugiausiai (90 proc.) Lietuvos aukštujų mokyklų ergonomikos mokymui naudoja medicinines lovas, kitų mokymo priemonių turi mažiau (4 pav.).

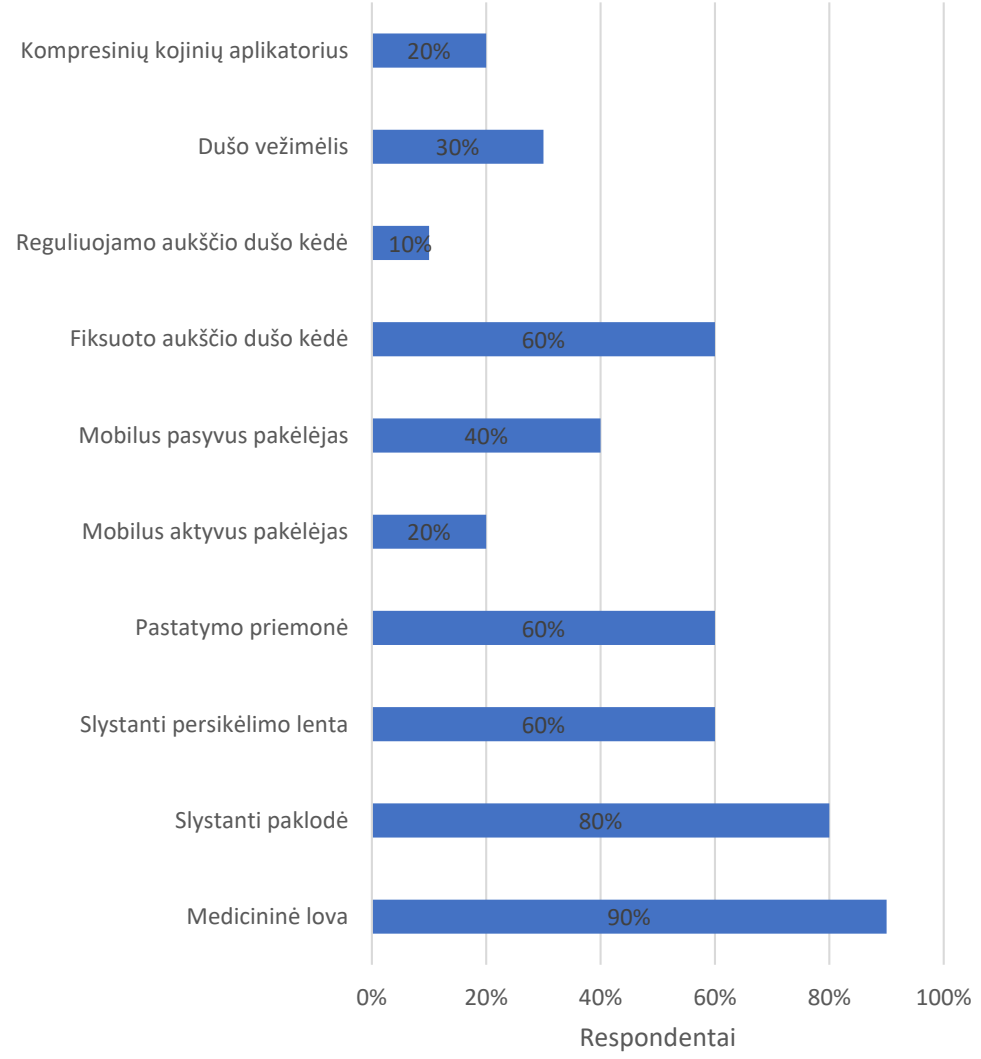

4 pav. Pagalbinès ergonomikos mokymui naudojamos priemonès Lietuvos aukštosiose mokyklose 


\section{DISKUSIJA}

Šio tyrimo tikslas - išsiaiškinti Lietuvos aukštujų mokyklų, rengiančių sveikatos priežiūros specialistus: kineziterapeutus, ergoterapeutus ir slaugytojus, ergonomikos dalyko poreikị ir turinị. Pagrindinis dalykas, ị kurị norime atkreipti dèmesị, yra tas, kad Europos lygmeniu nėra nacionalinių rekomendacijų dèl saugaus pacientų kūno padèties keitimo. Pacientų kèlimo, perkèlimo taisyklių nepakanka, nes paciento kūno padèties keitimas yra gana daugialypis manevras (Rogers, Buckheit, Ostendorf, 2013).

Anketinès apklausos duomenimis, skirtingos Lietuvos aukštosios mokyklos skiria skirtingą kreditų skaičių ergonomikos mokymui: nuo vieno iki penkių ECTS. Daugelyje Lietuvos mokyklų ergonomikos mokoma kaip atskiro dalyko, o trejose mokymo ịstaigose ergonomikos žinios yra integruotos ị kitas disciplinas. İrodyta, kad ergonomikos mokymo programos mokymo ịstaigose išlieka skirtingos, dažnai mokomi fiziškai sunkūs ir nesaugūs pacientų kūno padèties keitimo, perkèlimo metodai, stinga profesinès kokybès standartu ir mokymo medžiagos (Hermann, Michaelis, Schulz, 2014).

Dažniausias ir labiausiai paplitęs mokymo metodas Lietuvoje - tradicinė paskaita, kurią naudoja visos mokymo ịstaigos, ikiklinikinès pratybos, klinikinès pratybos ir simuliacijos, rečiausiai naudojamos - atvejų analizès. İdomu tai, kad tik dviejų aukštujų mokyklų atstovai nurodè, kad jų dèstomoje disciplinoje labai svarbu mokyti ergonomiško pacientų kūno padèties keitimo, daugiau nei pusè respondentų nurodè, kad - svarbu. Galima daryti prielaidą, kad respondentai dèsto ne specialiuosius, o bendruosius dalykus, nesusijusius su ikiklinikine arba klinikine praktika.

1990 m. Europos Sajunga (ES) prièmė direktyvą, skirtą apsaugoti darbuotojus nuo rizikos, susijusios su sunkių kroviniu kilnojimu (Tarybos direktyva 90/269/ EEB). Joje nurodyti minimalūs sveikatos ir saugos reikalavimai, kurie buvo ịgyvendinti daugelyje Europos šalių, rankiniam krovinių tvarkymui (Hignett et al. 2007). Tačiau paciento kūno padèties keitimas, perkèlimas yra sudètingesnis nei krovinių kèlimas, tad sveikatos priežiūros darbams atlikti reikia išsamesnių rekomendacijų (Galinsky, Hudock, Streit, 2010). Matyt, nekeista, kad pusė apklausoje dalyvavusių respondentų nurode, jog jų mokykloje ergonomikos mokymo kokybė yra sąlyginai gera. Nepaisant ịrodymų, patvirtinančių saugaus paciento kūno padèties keitimo, perkèlimo mokymo svarbą, nustatyta, kad to visuotinai nemokoma akademinèse programose (Powel-Cope et al., 2018, Tamminen-Peter et al., 2019).

Mokslininkai teigia, kad sveikatos priežiūros mokyklose vis dar mokoma senųjų nesaugių paciento kūno padèties keitimo būdų (Eberth, Provident, Chase, 2019; 
Perlow et al., 2016; Bocaut, Howson, 2018), tačiau sukurti ir igyvendinti mokymo programų pokyčius yra lètas ir sudètingas procesas.

Nustatyta, kad Lietuvoje ergonomikos dalyko mokymui naudojamos pagalbinès priemonès, tačiau tyrime dalyvavę respondentai nurodé, kad ne visas pagalbines priemones turi mokymo kabinetuose, teigdami, kad studentai turi galimybę susipažinti ir išbandyti jas klinikinès praktikos metu. Mokslininkai pabrež̌ia bendradarbiavimo svarbą tarp aukštujų mokyklų dẻstytojų ir klinikinės praktikos vadovų bendro požiūrio ị saugų pacientų kūno padèties keitimo ir perkèlimo mokymą (Kneafsey, Ramsay, Edwards, Callaghan, 2012).

Slaugytojai, ergoterapeutai ir kineziterapeutai kasdien susiduria su pacientu kūno padèties keitimo, persikèlimo ir judejimo sutrikimais (Kox et al., 2020), todèl būtina užtikrinti pakankamą mokymo valandų skaičių bei atsižvelgti į būsimo darbo specifiką, rengiant šiuos specialistus, siekiant sumažinti kaulų ir raumenu sistemos pažeidimo riziką.

Apibendrinant, galime teigti, kad nèra vieningos ir bendros nuostatos dèl ergonomikos dalyko mokymo Lietuvos aukštosiose mokyklose. Platesniam situacijos išsiaiškinimui ateityje reikètų atlikti didesnès imties tyrimus, analizuojant ergonomikos mokymo savitumus atskirose sveikatos priežiūros specialybėse. Nepaisant nustatytų skirtumų tarp aukštųų mokyklų ergonomikos dalyko turinio, dalyko svarba yra nebejotina.

\section{IŠVADOS}

Lietuvos aukštosiose mokyklose, rengiančiose kineziterapeutus, ergoterapeutus ir slaugytojus, ergonomikos mokymo turinys, metodologija ir turimos priemonès skiriasi. Siekiant, kad visi absolventai įgytų vienodas žinias ir įgūdžius, reikètų praplèsti ir suvienodinti mokymo turinį.

Finansavimas: nèra.

Interesų atskleidimas: nėra.

\section{LITERATŪRA}

Boucaut, R., \& Howson, D. (2018). Teaching safe patient handling skills using a peer approach. Radiologic technology, 90 (1), 20-30.

Cromie, J. E., Robertson, V. J., \& Best, M. O. (2000). Work-related musculoskeletal disorders in physical therapists: prevalence, severity, risks, and responses. Physical therapy, 80 (4), 336-351.

de Vries, J., Huijsman, R., Meijboom, B. et al. (2011). Supply chain management practices for improving patientoriented care. Supply Chain Management: An International Journal.

Eberth, S. D., Provident, I., \& Chase, C. (2019). Hybrid Learning to Develop Safe Patient Handling Judgement in Occupational Therapy Students. Journal of Occupational Therapy Education, 3 (3), 6. 
Ellen Perlow PT, D. P. T., Niamh Tunney, P. T., \& Ann Lucado, P. T. (2016). Integrating safe patient handling into physical therapist education: Reducing the incidence of physical therapist injury and improving patient outcomes. Journal of Physical Therapy Education, 30 (2), 32.

Galinsky, T., Hudock, S., \& Streit, J. (2010). Addressing the need for research on bariatric patient handling. Rehabilitation Nursing, 35 (6), 242-247.

Glover, W., McGregor, A., Sullivan, C., \& Hague, J. (2005). Work-related musculoskeletal disorders affecting members of the Chartered Society of Physiotherapy. Physiotherapy, 91 (3), 138-147.

Haleem, M. H., Ali, I., Khan, S., \& Jehangir, A. (2020). Work related musculoskeletal disorders in physical therapists; a systematic review. Rehman Journal of Health Sciences, 2 (2), 28-35.

Hermann, S., Michaelis, M., \& Schulz, A. (2014). Current situation in Germany and consequences for action. Project report.

Hignett, S., Fray, M., Rossi, M. A. et al. (2007). Implementation of the Manual Handling Directive in the healthcare industry in the European Union for patient handling tasks. International Journal of Industrial Ergonomics, 37 (5), 415-423.

Kneafsey, R., Ramsay, J., Edwards, H., \& Callaghan, H. (2012). An exploration of undergraduate nursing and physiotherapy students' views regarding education for patient handling. Journal of clinical nursing, 21 (2324), 3493-3503.

Kox, J. H., Bakker, E. J., Bierma-Zeinstra, S. et al. (2020). Effective interventions for preventing work related physical health complaints in nursing students and novice nurses: A systematic review. Nurse education in practice, 44, 102772.

Lövgren, M., Gustavsson, P., Melin, B., \& Rudman, A. (2014). Neck/shoulder and back pain in new graduate nurses: A growth mixture modeling analysis. International journal of nursing studies, 51 (4), 625-639.

McCrorie, P., Roberts, P. A., Sainsbury, D. et al. (2017). Perceptions of nursing and physical therapy students toward peer-led Interprofessional education in manual handling. Nurse educator, 42 (1), E1-E6.

Powell-Cope, G., Hughes, N., Sedlak, C., \& Nelson, A. (2008). Faculty perceptions of implementing an evidencebased safe patient handling nursing curriculum module. Online Journal of Issues in Nursing, 13 (3).

Rogers, B., Buckheit, K., \& Ostendorf, J. (2013). Ergonomics and nursing in hospital environments. Workplace health \& safety, 61 (10), 429-439.

Tamminen-Peter, L., Östring, E., \& Sormunen, E. (2019, July). Improving ergonomics competences in the social and health care sector in Finland. In International Conference on Healthcare Ergonomics and Patient Safety (pp. 90-98). Springer, Cham.

Verle Waters, M. A. (2009). Education evolution: A historical perspective of associate degree nursing. Journal of Nursing Education, 48 (5), 266.

Videman, T., Ojajärvi, A., Riihimäki, H., \& Troup, J. D. (2005). Low back pain among nurses: a follow-up beginning at entry to the nursing school. Spine, 30 (20), 2334-2341.

\title{
ERGONOMICS: SUBJECT CONTENT AND METHODOLOGY
}

\author{
Vilma Dudonienè ${ }^{1}$ (https://orcid.org/0000-0003-3954-9271) \\ Anelè Gedmantaité ${ }^{1}$, Eija Mammela ${ }^{2}$, Marion Karpi ${ }^{3}$ \\ Lithuanian Sports University ${ }^{1}$, Oulu University of Applied Sciences ${ }^{2}$, \\ Turku University of Applied Sciences ${ }^{3}$, Finland
}

\begin{abstract}
Background. Healthcare professionals often experience work-related musculoskeletal injuries due to improper patient handling methods. It is therefore im-
\end{abstract}


portant to teach students studying in health care study programmes the evidencebased contents and methods. Usually such knowledge is provided in courses of Ergonomics. Different educational institutions have different curricula and it is not clear whether graduates have acquired the adequate knowledge and skills.

Aim. To analyse the content of ergonomics training in different Lithuanian higher education institutions educating health care professionals and to identify differences between institutions.

Methods. Representatives of ten Lithuanian higher education institutions educating physiotherapists, occupational therapists and nurses completed a survey. The survey was carried out as a part of EU-project Renewing ergonomic education (RENE) for health care students in European HEIs, which involves six partner countries: Spain, Portugal, Finland, Estonia, Lithuania and Slovenia. The project aims to develop an international, evidence-based course on safe patient handling.

Results. It was found that in most (70 \%) higher education institutions that train health care professionals, the subject of Ergonomics is taught as an individual course with different credit points ranging from 1 to 5 ECTS, in some institutions (30\%) ergonomics knowledge is integrated into other courses. Subject content and methodology varied between institutions.

Conclusions. The content, methodology and available tools of Ergonomics differ between Lithuanian higher education institutions preparing physiotherapists, occupational therapists and nurses. In order for all graduates to have adequate knowledge and skills, the curriculum should be unified.

Keywords: ergonomics, patient care, subject content, methods.

Gautas 20210315

Priimtas 20210531 